\title{
PENGARUH PENGEMBANGAN BANDARA SILANGIT DAN PARIWISATA DALAM MENINGKATKAN PERTUMBUHAN EKONOMI DI SUMATERA UTARA
}

\author{
Tetty Tiurma Uli Sipahutar \\ Fakultas Ekonomi Universitas Prima Indonesia \\ Email: ratuhapis.tetty@gmail.com \\ Ahmad Rizki Harahap \\ Fakultas Pertanian Universitas Medan Area \\ Email: ahmadrizkiharahap@gmail.com
}

\begin{abstract}
Silangit Airport is an air transportation infrastructure located in Silangit, North Tapanuli, North Sumatra Province. The government has set Lake Toba as a tourism destination the main attraction for local and foreign tourists. With the continued development of regional tourism, the number of passengers and the number of tourists to SIlangit Airport will continue to increase and affect the regional economic growth which will have an impact on the figure of the North Sumatra Province GRDP. Therefore, the government has begun a big plan to advance Indonesian tourism starting from the construction of facilities and infrastructure in each tourist area. Lake Toba, located in Toba Samosir Regency, North Sumatra, is the largest lake in Indonesia, which is expected to bring more visits from various regions, both domestic and foreign. The aim of the study was to identify and analyze the problems of developing Silangit airport to support the acceleration of development in tourism. The results are recommendations for developing the Silangit airport area, including increasing accessibility and transportation connectivity from / to tourist locations throughout the region of Lake Toba tourism object by building Kualanamu-Parapat toll roads, Silangit-Parapat and feeder roads as well as adequate and then traffic smooth, safe, safe.
\end{abstract}

Keywords :Airlines, Passengers, Travelers, Unemployment, GDP

\section{PENDAHULUAN}

engembangan Bandara Silangit sebagai bagian dari sistem
transportasi udara sebagaimana dicanangkan pemerintah dengan
menganggarkan dana sebesar Rp 21 Triliun untuk membangun
infrastruktur dalam mendukung pertumbuhan ekonomi dan pariwisata kawasan Danau Toba di tahun 2019. Bandara Silangit dibangun pada masa penjajahan Jepang. Pembangunan kembali bandara ini mulai QE Journal |Vol.07 - No.03December 2018 - 174 
dilakukan sejak tahun 1995. Lalu, pada 14 Desember 2012, pemerintah melalui Kementerian Perhubungan secara resmi menyerahkan operasional pengelolaan Bandara Silangit kepada PT Angkasa Pura II (Persero) yang tadinya merupakan bandara untuk penerbangan perintis bersubsidi berubah status menjadi bandara internasional dengan selling point keindahaan wisata kawasan Danau Toba. Kehadiran bandara Silangit memberikan dampak positif bagi sektor pariwisata dan perekonomian masyarakat sekitar dengan cara semakin menarik minat wisatawan domestik hingga mancanegara untuk berkunjung ke Danau Toba mengingat pemerintah telah mencanangkan Danau Toba sebagai salah satu dari 10 tujuan wisata prioritas atau sebagai "10 Bali Baru" dengan target kunjungan wisatawan mancanegara ke Sumatera Utara diproyeksikan mencapai sejuta orang pada 2019. Sehingga pemerintah melakukan pengembangan Bandara Silangit, Tapanuli Utara, Sumatera Utara, senilai Rp 369 Milliar yang akan tuntas pada September 2017 didukung pembukaan rute baru diperkirakan pergerakan penumpang dapat mencapai 300.000 hingga 500.000 penumpang.

Bandara Silangit disiapkan menjadi Bandara Internasional sebagai salah satu perintis/pionir penerapan konsep bandara pintar (smart airport) dengan berbagai fasilitas dengan fitur teknologi digital yang dapat digunakan sejak 28 Oktober 2017 bersamaan dengan penerbangan rute perdana Singapura-Silangit akan dilayani sebanyak tiga kali dalam satu pekan dengan pesawat Bombardier CRJ 1000 berkapasitas 96 penumpang, dan gerbang bagi wisatawan lokal maupun asing untuk berkunjung dan melestarikan budaya adat Batak dan Danau Toba, membangun kampung halaman dan gerbang menuju kemakmuran dan kesejahteraan masyarakat setempat dengan mengembangkan sumber daya manusia yang baik. Hal tersebut dapat dilihat melalui adanya training kepada para karyawan untuk dapat memahami lini kerjanya, dan masuknya tenaga kerja baru di bandara dapat mambantu lini kerja yang kosong, selain itu adanya bandara baru maka berpeluang untuk masuknya berbagai masakapai lain yang lebih besar (Karel, 2014).

Menurut Sukirno (2011:120) pertumbuhan ekonomi diartikan sebagai perkembangan kegiatan dalam perekonomian yang menyebabkan barang dan jasa yang diproduksi dalam masyarakat bertambah dan kemakmuran masyarakat meningkat. Indikator mengukur pertumbuhan ekonomi di 
suatu daerah berupa Produk Domestik Regional Bruto (PDRB) yang merupakan sasaran utama bagi proses pembangunan suatu daerah. Model pertumbuhan ekonomi neo klasik yang dikembangkan oleh Solow (1970) dan Swan (1956), menggunakan unsur pertumbuhan penduduk, akumulasi kapital, tenaga kerja, kemajuan teknologi dan besarnya output yang saling berinteraksi. Dalam bentuknya yang lebih formal, model pertumbuhan Neo Klasik Solow memakai fungsi agregat standar (Todaro, 2010):

$$
\mathrm{Y}=\mathrm{Ae}^{\mu \mathrm{ut}} \cdot \mathrm{K}^{\alpha} \cdot \mathrm{L}^{1-\alpha}
$$

dimana:

$\mathrm{Y}=$ Produk Domestik Bruto

$\mathrm{K}=$ stok modal fisik dan modal manusia

$\mathrm{L}=$ tenaga kerja non terampil

A $=$ konstanta yang merefleksikan tingkatan tekonologi dasar

$\mathrm{e} \mu \mathrm{t}=$ melambangkan tingkat kemajuan teknologi

$\mathrm{a}=$ melambangkan elastisitas output terhadap model, yaitu persentase kenaikan

Selain pengembangan bandara Silangit, perlu juga pembenahan dan pembangunan sejumlah aksebilitas yang memudahkan serta mendukung pintu kedatangan wisatawan bervariasi menuju kawasan wisata Danau Toba, seperti jalan tol yang akan direncanakan jalur tol dari Kualanamu ke Tebing Tinggi, menuju Siantar, hingga Parapat; kunjungan wisatawan yang menggunakan kapal cruise dan kapal pesiar dari pelabuhan Kuala Tanjung, di pantai Timur Sumatera Utara; pembukaan jalur kereta api yang baru dan pemanfaatan jalur yang sudah ada, seperti jalur kereta api MedanPematang Siantar, akan ditingkatkan dengan penambahan rangkaian kereta baru kelas eksekutif; menyediakan transportasi bus Damri gratis bagi penumpang pesawat rute Pangururan-Bandara Silangit. Disamping pengembangan dan pembangunan aksebilitas, melalui pembenahan dan pembangunan Bandara Silangit Siborong-borong Tapanuli Utara yang kini telah menjadi bandara internasional dan juga pembenahan bandara Sibisa Ajibata, Kabupaten Toba Samosir.

Pemakaian fasilitas transportasi angkutan udara mempunyai dampak pada pertumbuhan pariwisata. Fasilitas bandara yang tersedia cukup aman dan terjangkau semakin mendapat tempat pengunjung untuk berkunjung. Hal ini dapat memicu pertumbuhan ekonomi dengan adanya peningkatan 
jumlah wisatawan dan pengembangan bandara semakin bertambah jumlah penumpang maskapai. Aksesibilitas merupakan fungsi utama dasar angkutan pariwisata. Untuk mengakses lokasi yang merupakan tujuan utama, maka wisatawan akan menggunakan moda transportasi. (Tambunan, 2009)

Jumlah lalu lintas udara sebagai faktor penting dalam meningkatkan jumlah penumpang adalah variabel yang sama yang digunakan oleh (Leurent, 2011) yang menjelaskan frekuensi layanan yang mempengaruhi jumlah penumpang yang diangkut di setiap stasiun, menunjukkan jumlah frekuensi yang menunjukkan daya dukung selain jumlah kursi yang tersedia dalam sistem angkutan massal.Peran infrastruktur tidak hanya berpengaruh pada pengembangan wilayah saja, tetapi juga pada bidang kepariwisataan. Infrastruktur berperan sangat penting dalam mendorong kualitas wisata itu sendiri, serta pada lingkungan sekitarnya (Afandi, 2010). Lebih lanjut, dengan kebijakan pembangunan yang digalakkan oleh pemerintah dalam kurun waktu dua tahun terakhir dengan membuka akses terhadap pembentukan 10 destinasi wisata baru sangat menarik untuk dikaji. Konektivitas sebagai isu penting dalam pariwisata maka membutuhkan perangkat pendukung berupa pelabuhan, bandara, pembuatan jalur dan jadwal pelayaran kapal dan lain-lain serta pembangunan infrastruktur pendukung adalah sebuah kemajuan yang tidak bisa dipungkiri. (Mentari, 2016).

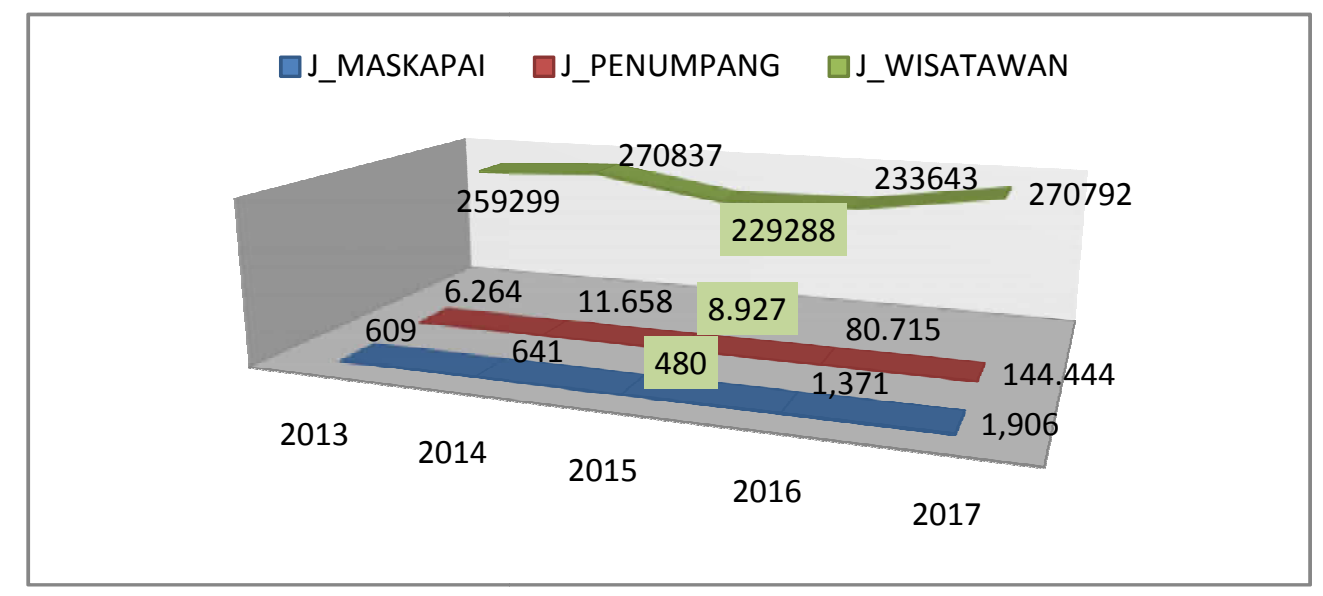

Sumber: Kurs Tengah Bank Indonesia

Gambar 1.1 Perkembangan Jumlah Maskapai, Jumlah Penumpang, Jumlah Wisatawan di Bandara Silangit Tahun 2013-2017 
Perkembangan penumpang dan pesawat udara pada Bandara Silangit setiap tahunnya mengalami peningkatan baik, sejak bandara ini diperluas dan ditingkatkan kapasitasnya ditambah lagi dengan promosi gencar, jumlah penumpang di Bandara Silangit ini meningkat lebih 14 kali lipat atau $1.400 \%$. Sejumlah maskapai yang sudah melayani penerbangan di Silangit adalah Garuda Indonesia, Sriwijaya Air, Wings Air dan rencananya awal Desember 2017 Batik Air. Hal tersebut didukung sejumlah faktor seperti pembukaan rute baru oleh maskapai penerbangan Lion Air dan Citilink yang akan diumumkan dalam waktu dekat. Penerbangan akan dilangsungkan empat kali dalam seminggu, rute penerbangan ini dapat menarik wisatawan mancanegara (wisman) dari Thailand, Cina, India, dan sekitarnya. Keterisian penumpang penerbangan Malindo Air dan Air Asia dari Malaysia ke Bandara Internasional Silangit punya perkembangan signifikan. Hal itu membuat seluruh pelaku pariwisata di Danau Toba harus bisa mempersiapkan sambutan yang sangat cocok untuk wisatawan dari negeri jiran tersebut. Dengan rute Kualanamu Sumatera Utara dan Hang Nadim Batam, sekarang sudah ada Wings dan Susi Air. Jadi di bandara ini ATR dan Bombardier sudah bisa beroperasi di bandara. (PT Angkasa Pura II, 2017)

Hasil penelitian terdahulu oleh beberapa peneliti yang memiliki ruang lingkup kajian memiliki kemiripan yang diantaranya, adalah:

1. Penelitian yang sama dilakukan oleh Bojanic dan Lo (2016), menemukan bahwa pariwisata sangat berpengaruh pada pertumbuhan ekonomi di sebagian besar negara-negara terutama negara yang terdiri dari pulau-pulau. Negara kepulauan memiliki lebih banyak obyek wisata sehingga pendapatan dari pajak dan retribusi yang diperoleh melalui obyek wisata tersebut mampu mendongkrak pertumbuhan ekonomi daerah.

2. Hasil studi selanjutnya dikemukakan oleh Jalil (2013) di Pakistan, menunjukkan bahwa jumlah wisatawan mancanegara atau wisatawan internasional berpengaruh positif pada pertumbuhan ekonomi di Pakistan.

3. Penelitian Padmasani (2014). Hasil penelitian menunjukkan bahwa dari tahun - ke tahun sektor pariwisata berkembang pesat, hal ini di tandai oleh peningkatan kunjungan wisatawan asing maupun lokal 
yang berkunjung ke Sulawesi selatan serta kontribusi sektor pariwisata terhadap pendapatan daerah (PDRB). Perkembangan sektor ini juga berdampak pada penyerapan tenaga kerja di Sulawesi Selatan namun belum berdampak pada perkembangan ekonomi kreatif.

4. Kurniawan (2015) melakukan penelitian berjudul, “Dampak Sosial Ekonomi Pembangunan Pariwisata Umbul Sidomukti KecamatanBandungan Kabupaten Semarang". Hasil penelitian menunjukkan peluang usaha di sekitar objek pariwisata Umbul Sidomukti termasuk dalam kategori tinggi. Masyarakat sekitar memanfaatkan situasi ini untuk berdagang, jasa tour leader hingga menjadi karyawan objek pariwisata Umbul Sidomukti.Peningkatan pengunjung pasca renovasi. Objek Pariwisata Umbul Sidomukti benarbenar mampu meningkatkan pengunjung dan mempengaruhi peningkatan pendapatan. Pembangunan Umbul Sidomukti berhasil menyerap banyak tenaga kerja mengingat banyak wahana baru yang disediakan, pembangunan Objek Wisata Umbul Sidomukti benarbenar mampu menyerap tenaga kerja yang cukup banyak. Tidak hanya tenaga kerja di sektor pariwisata saja yang terserap, kenaikan omset penjualan yang dialami para pedagang disekitar Umbul Sidomukti juga memaksa para pedagang untuk menambah karyawannya, lambat laun jumlah pengangguran di sekitar Objek WisataUmbul Sidomukti mulai menurun. Penurunan jumlah pengangguran dan peningkatan pendapatan masyarakat ternyata berdampak positif pada kondisi sosial ekonomi masyarakat sekitar. Walaupun demikian aroma persaingan usaha antar sesama pedagang makin terasa.

5. Hasan (2013), Economic Impact Of An Increase In The Foreign Tourism Receipts: A SAM-Based Income Multiplier Analysis For Turkey. Menganalisis dampak peningkatan permintaan pariwisata terhadap sektor pariwisata, industri lainnya, penyerapan tenaga kerja, dan pendapatan.

\section{METODE PENELITIAN}

Pengolahan data pada penelitian ini menggunakan metode kuantitatif Error Correction Model (ECM). Error Correction Model adalah suatu bentuk model yang digunakan untuk mengetahui pengaruh jangka pendek dan 
jangka panjang variabel bebas terhadap variabel terikat. Pada penelitian ini, dalam menganalisis data menggunakan software Microsoft Excel 2007 dan kemudian diolah menggunakan E-Views 9.0. Variabel independen yang mempengaruhi variabel dependen dinyatakan dalam fungsi sebagai berikut:

$$
Y_{1}=f\left(X_{1}, X_{2}, X_{3} X_{4}\right)
$$

Kemudian fungsi tersebut ditransformasikan kedalam model persamaan linear berganda (multiple regression) dengan spesifikasi model seperti dibawah ini, sehingga model itu berubah menjadi bentuk linier, seperti dibawah ini:

$$
\log \left(P D R B_{i t}\right)=\alpha+\beta_{1} \log \left(X_{1 i t}\right)+\beta_{2} \log \left(X_{2 i t}\right)+\beta_{3} \log \left(X_{3 i t}\right)+\beta_{4} \log \left(X_{4 i t}\right)+
$$

Dengan penjelasan sebagai berikut:

$Y_{1} \quad$ : PDRB

$X_{1} \quad$ : Jumlah Maskapai

$X_{2} \quad$ : Jumlah Penumpang

$X_{3}$ : Jumlah Wisatawan

$X_{4} \quad$ : Pengangguran Terbuka

$\log \quad$ : Logaritma

$\beta_{1} \beta_{2} \beta_{3}$ : Koefisien Regresi

$v_{i t} \quad$ : Kesalahan Pengganggu (error term)

$t$ : waktu

Two steps model (model dua langkah) dari Engle-Granger. Secara umum model dasar Engle-Granger adalah sebagai berikut: (Widarjono, 2013:322)

$$
\Delta Y_{t}=\alpha_{0}+\alpha_{1} \Delta X_{t}+\alpha_{2} E C_{t}+e_{t}
$$

Dimana:

$$
E C_{t}=\left(Y_{t-1}-\beta_{0}-\beta_{1} X_{t-1}\right)
$$

Dalam hal ini $\Delta$ merupakan perbedaan pertama (first difference), koefisien $\alpha_{1}$ adalah koefisien jangka pendek sedangkan $\beta_{1}$ adalah koefisien jangka panjang. Menurut model ini, model ECM valid jika tanda koefisien koreksi kesalahan bertanda negatif dan secara statistic signifikan. (Gujarati, 2010:459). 


\section{HASIL DAN PEMBAHASAN}

Pengujian Stasioneritas (Unit Root Test)

Uji akar-akar unit dipandang sebagai uji stasioner karena pada prinsipnya uji tersebut dimaksudkan untuk mengamati apakah koefisien tertentu dari model autorgresif yang ditaksir mempunyai nilai satu atau tidak (Gujarati, 2010). Stasioner data runtun waktu mensyaratkan rata-rata dan varians yang konstan dan fungsi autokorelasi yang hanya tergantung pada panjangnya kelambanan waktu (Studenmund, 1997).

\section{Tabel 4.1 Tabel Uji Stasioneritas}

Null Hypothesis: Unit root (individual unit root process)

Series: LNJ_MASKAPAI, LNJ_PENGANGGURAN,

LNJ_PENUMPANG, LNJ_WISATAWAN, LNPDRB

Date: 02/12/19 Time: 18:31

Sample: 2013Q1 2017Q4

Exogenous variables: Individual effects

Newey-West automatic bandwidth selection and Bartlett kernel

Total (balanced) observations: 95

Cross-sections included: 5

\begin{tabular}{lcc}
\hline \hline Method & Statistic & Prob.** \\
\hline PP - Fisher Chi-square & 5.20715 & 0.8769 \\
PP - Choi Z-stat & 1.25074 & 0.8945 \\
\hline \hline
\end{tabular}

** Probabilities for Fisher tests are computed using an asymptotic Chi-square distribution. All other tests assume asymptotic normality.

Intermediate Phillips-Perron test results UNTITLED

\begin{tabular}{cccc}
\hline \hline & & & \\
Series & Prob. & Bandwidth & Obs \\
\hline $\begin{array}{c}\text { LNJ_MASKAPAI } \\
\text { LNJ_PENGANGG } \\
\text { URAN }\end{array}$ & 0.8830 & 2.0 & 19 \\
$\begin{array}{c}\text { LNJ_PENUMPAN } \\
\text { G }\end{array}$ & 0.8959 & 2.0 & 19 \\
LNJ_WISATAWA & 0.8183 & 0.0 & 19 \\
N & 0.6409 & 3.0 & 19 \\
LNPDRB & 0.1784 & 2.0 & 19 \\
\hline \hline
\end{tabular}


Karena hasil pengujian yang diinginkan adalah seluruh variabel tidak stasioner pada Level, nilai probabilitas masing-masing variabel lebih besar dari alpha 0.05 .

Null Hypothesis: Unit root (individual unit root process)

Series: LNJ_MASKAPAI, LNJ_PENGANGGURAN,

LNJ_PENUMPANG, LNJ_WISATAWAN, LNPDRB

Date: 02/12/19 Time: 18:32

Sample: 2013Q1 2017Q4

Exogenous variables: Individual effects

Newey-West automatic bandwidth selection and Bartlett kernel

Total (balanced) observations: 90

Cross-sections included: 5

\begin{tabular}{lcc}
\hline \hline Method & Statistic & Prob.** \\
\hline PP - Fisher Chi-square & 20.7551 & 0.0229 \\
PP - Choi Z-stat & -2.25195 & 0.0122 \\
\hline \hline
\end{tabular}

** Probabilities for Fisher tests are computed using an asymptotic Chi-square distribution. All other tests assume asymptotic normality.

Intermediate Phillips-Perron test results D(UNTITLED)

\begin{tabular}{cccc}
\hline \hline Series & Prob. & Bandwidth & Obs \\
\hline $\begin{array}{c}\text { D(LNJ_MASKAPAI } \\
\text { ) }\end{array}$ & 0.1253 & 1.0 & 18 \\
$\begin{array}{c}\text { D(LNJ_PENGANG } \\
\text { GURAN) }\end{array}$ & 0.2484 & 1.0 & 18 \\
$\begin{array}{c}\text { D(LNJ_PENUMPA } \\
\text { NG) }\end{array}$ & 0.0115 & 1.0 & 18 \\
$\begin{array}{c}\text { D(LNJ_WISATAW } \\
\text { AN) }\end{array}$ & 0.5043 & 1.0 & 18 \\
D(LNPDRB $)$ & 0.1726 & 1.0 & 18 \\
\hline \hline
\end{tabular}

Langkah uji stasioneritas dengan level data $\mathbf{1}^{\text {st }}$ difference menunjukkan seluruh variabel tidak stasioner, nilai probabilitas masing-masing variabel lebih besar dari alpha 0.05 .

Langkah uji stasioneritas dengan level data $2^{\text {st }}$ difference menunjukkan seluruh variabel stasioner pada tahap ini (difference kedua), nilai probabilitas masing-masing variabel berada di bawah alpha 0.05 . 
Null Hypothesis: Unit root (individual unit root process)

Series: LNJ_MASKAPAI, LNJ_PENGANGGURAN,

LNJ_PENUMPANG, LNJ_WISATAWAN, LNPDRB

Date: 02/12/19 Time: 18:33

Sample: 2013Q1 2017Q4

Exogenous variables: Individual effects

Newey-West automatic bandwidth selection and Bartlett kernel

Total (balanced) observations: 85

Cross-sections included: 5

\begin{tabular}{lcc}
\hline \hline Method & Statistic & Prob. $^{* *}$ \\
\hline PP - Fisher Chi-square & 125.401 & 0.0000 \\
PP - Choi Z-stat & -9.04545 & 0.0000 \\
\hline \hline
\end{tabular}

** Probabilities for Fisher tests are computed using an asymptotic Chi-square distribution. All other tests assume asymptotic normality.

Intermediate Phillips-Perron test results D(UNTITLED,2)

\begin{tabular}{cccc}
\hline \hline Series & Prob. & Bandwidth & Obs \\
\hline $\begin{array}{c}\text { D(LNJ_MASKAPAI } \\
\text { 2) }\end{array}$ & 0.0008 & 1.0 & 17 \\
$\begin{array}{c}\text { D(LNJ_PENGANG } \\
\text { GURAN,2) }\end{array}$ & 0.0011 & 0.0 & 17 \\
$\begin{array}{c}\text { D(LNJ_PENUMPA } \\
\text { NG,2) }\end{array}$ & 0.0000 & 11.0 & 17 \\
$\begin{array}{c}\text { D(LNJ_WISATAW } \\
\text { AN,2) }\end{array}$ & 0.0023 & 1.0 & 17 \\
D(LNPDRB,2) & 0.0010 & 0.0 & 17 \\
\hline \hline
\end{tabular}

Output di atas memberikan informasi bahwa variabel ECT stasioner pada level data $1^{\text {st }}$ difference, dan secara tersirat menyatakan bahwa $Y, X 1, X 2$, X3 saling berkointegrasi.

Nilai F-statistic lebih kecil dari alpha (0.05). namun variabel J-Maskapai, J_Penumpang, dan J_Wisatawan tidak berpengaruh signifikan terhadap PDRB. 


\section{Hasil Uji Kointegrasi (Cointegration Test)}

\section{Tabel 4.2 Tabel Uji Kointegrasi Phillips-Perron}

Null Hypothesis: D(ECT,2) has a unit root

Exogenous: Constant

Bandwidth: 6 (Newey-West automatic) using Bartlett kernel

\begin{tabular}{|c|c|c|c|}
\hline & & Adj. t-Stat & Prob.* \\
\hline \multicolumn{2}{|c|}{ Phillips-Perron test statistic } & -6.188877 & 0.0001 \\
\hline \multirow[t]{3}{*}{ Test critical values: } & $1 \%$ level & -3.886751 & \\
\hline & $5 \%$ level & -3.052169 & \\
\hline & $10 \%$ level & -2.666593 & \\
\hline
\end{tabular}

*MacKinnon (1996) one-sided p-values.

Warning: Probabilities and critical values calculated for 20 observations and may not be accurate for a sample size of 17

Residual variance (no correction)

Phillips-Perron Test Equation

Dependent Variable: D(ECT,3)

Method: Least Squares

Date: 02/12/19 Time: 18:38

Sample (adjusted): 2013Q4 2017Q4

Included observations: 17 after adjustments

\begin{tabular}{lrrrr}
\hline \hline \multicolumn{1}{c}{ Variable } & Coefficient & \multicolumn{1}{c}{ Std. Error } & t-Statistic & Prob. \\
\hline \hline \multicolumn{1}{c}{ D(ECT(-1),2) } & -1.317628 & 0.244299 & -5.393507 & 0.0001 \\
\multicolumn{1}{c}{ C } & 0.001536 & 0.002049 & 0.749699 & 0.4650 \\
\hline \hline R-squared & 0.659786 & Mean dependent var & 0.000163 \\
Adjusted R-squared & 0.637105 & S.D. dependent var & 0.013917 \\
S.E. of regression & 0.008384 & Akaike info criterion & -6.614927 \\
Sum squared resid & 0.001054 & Schwarz criterion & -6.516902 \\
Log likelihood & 58.22688 & Hannan-Quinn criter. & -6.605183 \\
F-statistic & 29.08992 & Durbin-Watson stat & 2.184756 \\
Prob(F-statistic) & 0.000075 & & \\
\hline \hline
\end{tabular}


Estimasi Persamaan Jangka Panjang

Tabel 4.3 Tabel Jangka Panjang

Dependent Variable: LNPDRB

Method: Least Squares

Date: 02/12/19 Time: 18:34

Sample: 2013Q1 2017Q4

Included observations: 20

\begin{tabular}{lrcrr}
\hline \hline \multicolumn{1}{c}{ Variable } & Coefficient & \multicolumn{1}{c}{ Std. Error } & t-Statistic & \multicolumn{1}{c}{ Prob. } \\
\hline \multicolumn{1}{c}{ C } & 27.90919 & 1.241299 & 22.48385 & 0.0000 \\
LNJ_MASKAPAI & -0.131683 & 0.026545 & -4.960721 & 0.0002 \\
LNJ_PENGANGGURA & & & & \\
$\quad$ N & -3.974424 & 0.323352 & -12.29133 & 0.0000 \\
LNJ_PENUMPANG & 0.009234 & 0.011595 & 0.796356 & 0.4382 \\
LNJ_WISATAWAN & -1.074389 & 0.083456 & -12.87372 & 0.0000 \\
\hline \hline R-squared & 0.978449 & Mean dependent var & 11.61041 \\
Adjusted R-squared & 0.972702 & S.D. dependent var & 0.074305 \\
S.E. of regression & 0.012277 & Akaike info criterion & -5.749919 \\
Sum squared resid & 0.002261 & Schwarz criterion & -5.500986 \\
Log likelihood & 62.49919 & Hannan-Quinn criter. & -5.701324 \\
F-statistic & 170.2578 & Durbin-Watson stat & 0.519150 \\
Prob(F-statistic) & 0.000000 & & \\
\hline \hline
\end{tabular}

Untuk persamaan jangka pendek, nilai probabilitas F-statistic berada di bawah alpha (0.05). Speed of adjustment-nya koefisien dari ECT(2), nilai koefisien tersebut negatif dan signifikan (probabilitasnya berada dibawah 0.05). hanya variabel J_Penumpang yang berpengaruh signifikan, sedangkan variabel J-Maskapai, dan J_Wisatawan tidak signifikan terhadap PDRB.

Hasil yang ditampilkan pada tabel 4.4. Variabel koreksi kesalahan (ECT) bertanda negatif dan secara signifikan berarti model spesifikasi ECM produk domestik regional bruto (PDRB) yang digunakan dalam penelitian ini valid. Persamaan model ECM-nya sebagai berikut :

$$
\begin{aligned}
& d(\ln (P D R B))=0.012447-0.002137 d\left(\ln \left(j \_ \text {maskapai }\right)\right)-0.042574 \\
& d\left(\ln \left(j \_ \text {pengangguran }\right)\right)+0.000348 d\left(\ln \left(j \_ \text {penumpang }\right)\right)-0.008941 \\
& d\left(\ln \left(j_{2} \text { wisatawan }\right)\right)-0.007522 E C_{(2)}+\varepsilon
\end{aligned}
$$




\section{Estimasi Persamaan Jangka Pendek}

\section{Tabel 4.4 Tabel Jangka Pendek}

Dependent Variable: D(LNPDRB)

Method: Least Squares

Date: 02/12/19 Time: 18:46

Sample (adjusted): 2013Q2 2017Q2

Included observations: 17 after adjustments

\begin{tabular}{lrcrr}
\hline \hline \multicolumn{1}{c}{ Variable } & Coefficient & Std. Error & t-Statistic & Prob. \\
\hline \multicolumn{1}{c}{ C } & 0.012447 & $4.70 \mathrm{E}-05$ & 264.9771 & 0.0000 \\
D(LNJ_MASKAPAI) & -0.002137 & 0.000567 & -3.770158 & 0.0031 \\
D(LNJ_PENGANGGURAN) & -0.042574 & 0.013799 & -3.085307 & 0.0104 \\
D(LNJ_PENUMPANG) & 0.000348 & $8.50 \mathrm{E}-05$ & 4.094645 & 0.0018 \\
D(LNJ_WISATAWAN) & -0.008941 & 0.003927 & -2.276722 & 0.0438 \\
\multicolumn{1}{c}{ ECT(2) } & -0.007522 & 0.002207 & -3.407933 & 0.0058 \\
\hline \hline R-squared & 0.907106 & Mean dependent var & 0.012605 \\
Adjusted R-squared & 0.864881 & S.D. dependent var & 0.000204 \\
S.E. of regression & $7.50 \mathrm{E}-05$ & Akaike info criterion & -15.88682 \\
Sum squared resid & $6.19 \mathrm{E}-08$ & Schwarz criterion & -15.59275 \\
Log likelihood & 141.0380 & Hannan-Quinn criter. & -15.85759 \\
F-statistic & 21.48285 & Durbin-Watson stat & 0.956010 \\
Prob(F-statistic) & 0.000025 & & \\
\hline \hline
\end{tabular}

Tabel 4.5 Uji Normalitas

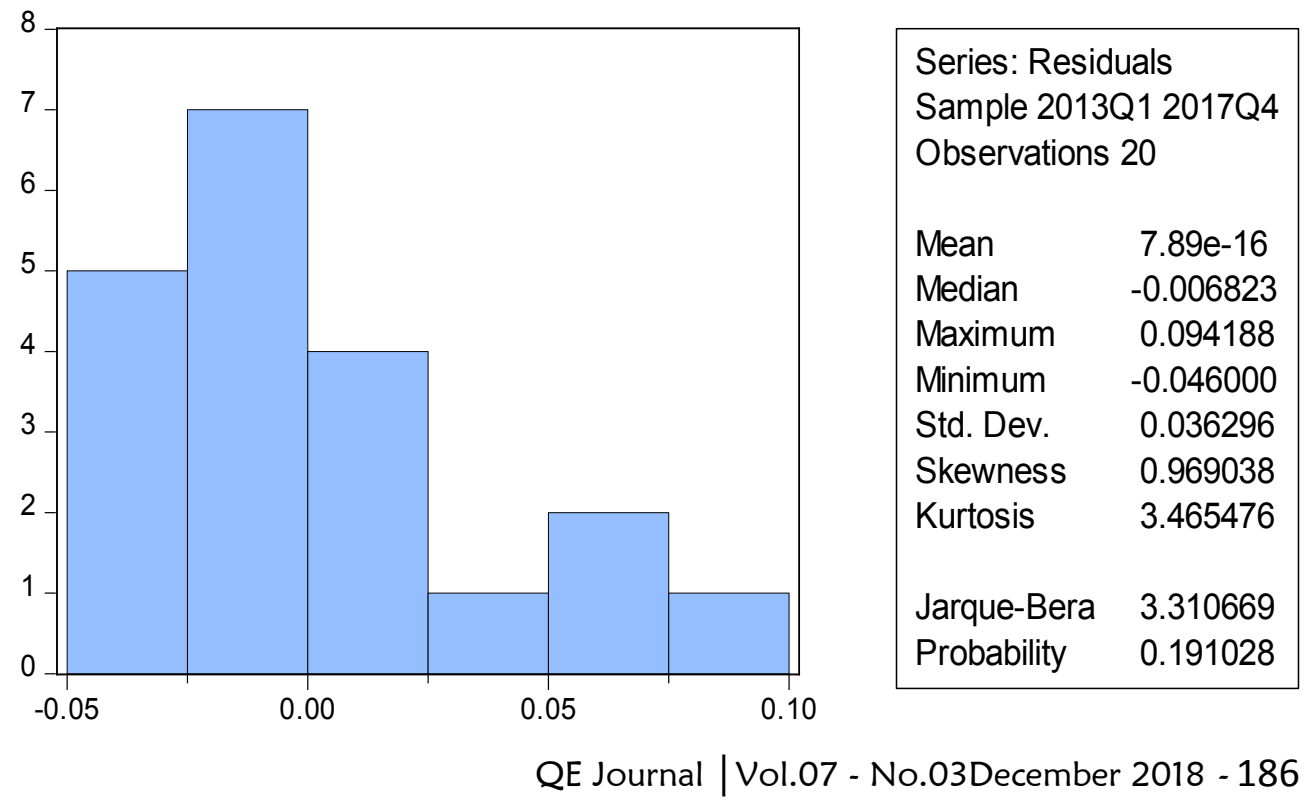


Berdasarkan parameter ini diketahui bahwa besaran nilai probabilitas pada JB adalah 0,191028, lebih besar dibanding nilai 0,05, Dengan demikian dapat disimpulkan bahwa model regresi memenuhi asumsi normalitas.

Tabel 4.6 Hasil Uji Multikolinieritas

\begin{tabular}{llllll}
\hline & LNPDRB & $\begin{array}{l}\text { LNJ_MA } \\
\text { SKAPAI }\end{array}$ & $\begin{array}{l}\text { LNJ_PEN } \\
\text { GANGGU } \\
\text { RAN }\end{array}$ & $\begin{array}{l}\text { LNJ_PENUM } \\
\text { PANG }\end{array}$ & $\begin{array}{l}\text { LNJ_WI } \\
\text { SATAW } \\
\text { AN }\end{array}$ \\
\hline LNPDRB & 1.000000 & 0.802462 & -0.714406 & 0.850007 & -0.067466 \\
$\begin{array}{l}\text { LNJ_MASKAP } \\
\text { AI }\end{array}$ & 0.802462 & 1.000000 & -0.883494 & 0.973918 & 0.244006 \\
$\begin{array}{l}\text { LNJ_PENGAN } \\
\text { GGURAN }\end{array}$ & -0.714406 & -0.883494 & 1.000000 & -0839356 & -0.612180 \\
$\begin{array}{l}\text { LNJ_PENUMPA } \\
\text { NG }\end{array}$ & 0.850007 & 0.973918 & -0.839356 & 1.000000 & 0.147795 \\
$\begin{array}{l}\text { LNJ_WISATAW } \\
\text { AN }\end{array}$ & -0.067466 & 0.244006 & -0.612180 & 0.147795 & 1.000000 \\
\hline
\end{tabular}

Semua variabel independen memiliki nilai koefisien korelasi di bawah 10 sehingga dapat disimpulkan model ECM bebas dari gejala multikolinieritas.

Menurut tabel Durbin-Watson menunjukkan bahwa nilai $\mathrm{dL}=1.4643$ dan nilai dU $=1.9622$ Tidak Ada Autokorelasi. Dapat ditentukan kriteria terjadi atau tidaknya autokorelasi seperti terlihat pada gambar di bawah ini.

Hasil Pengujian Hipotesis Secara Partial (Uji t-statistik)

Dalam jangka panjang nilai t-statistik dan probabilitasnya masing-masing variabel J_Maskapai $\mathrm{t}$-statistik $=-4.960721$ (prob $=0.0002)$ menunjukkan bahwa berpengaruh negatif dan signifikan; variabel J_Pengangguran $t$ statistik $=-12.29133$ (prob $=0.0000)$ menunjukkan bahwa berpengaruh negatif dan signifikan; variabel J_Penumpang t-statistik $=0.796356$ (prob $=$ 0.4382 ) menunjukkan bahwa berpengaruh positif dan tidak signifikan; dan variabel J_Wisatawan t-statistik $=-12.87372$ (prob $=0.0000)$ menunjukkan bahwa berpengaruh negatif dan signifikan mempengaruhi PDRB Sumatera Utara.

Dalam jangka pendek nilai t-statistik dan probabilitasnya masing-masing variabel J_Maskapai t-statistik $=-3.770158$ (prob $=0.0031)$ menunjukkan bahwa berpengaruh negatif dan signifikan; variabel J_Pengangguran $t$ statistik $=-3.085307$ (prob $=0.0104)$ menunjukkan bahwa berpengaruh QE Journal | Vol.07 - No.03December 2018 - 187 
negatif dan signifikan; variabel J_Penumpang t-statistik $=4.094645$ (prob $=$ 0.0018) menunjukkan bahwa berpengaruh positif dan signifikan; dan variabel J_Wisatawan t-statistik $=-3.407933$ (prob $=0.0058)$ menunjukkan bahwa berpengaruh negatif dan signifikan mempengaruhi PDRB Sumatera Utara.

Tabel 4.7 Hasil Uji Autokorelasi

Breusch-Godfrey Serial Correlation LM Test:

\begin{tabular}{lllr}
\hline \hline F-statistic & 8.446936 & Prob. F(2,13) & 0.0045 \\
Obs*R-squared & 11.30257 & Prob. Chi-Square(2) & 0.0035 \\
\hline \hline
\end{tabular}

Test Equation:

Dependent Variable: RESID

Method: Least Squares

Date: 02/12/19 Time: 17:49

Sample: 2013Q1 2017Q4

Included observations: 20

Presample missing value lagged residuals set to zero.

\begin{tabular}{|c|c|c|c|c|}
\hline Variable & Coefficient & Std. Error & $\mathrm{t}$-Statistic & Prob. \\
\hline $\mathrm{C}$ & 0.227465 & 0.979865 & 0.232139 & 0.8200 \\
\hline LNJ_MASKAPAI & -0.001720 & 0.019051 & -0.090259 & 0.9295 \\
\hline LNJ_PENGANGGURAN & -0.084392 & 0.266690 & -0.316441 & 0.7567 \\
\hline LNJ_PENUMPANG & -0.001055 & 0.008465 & -0.124627 & 0.9027 \\
\hline LNJ_WISATAWAN & -0.012344 & 0.064429 & -0.191593 & 0.8510 \\
\hline $\operatorname{RESID}(-1)$ & 1.085266 & 0.268535 & 4.041426 & 0.0014 \\
\hline $\operatorname{RESID}(-2)$ & -0.491030 & 0.320466 & -1.532239 & 0.1494 \\
\hline R-squared & 0.565128 & Mean dependent var & & $7.28 \mathrm{E}-15$ \\
\hline Adjusted R-squared & 0.364418 & S.D. dependent var & & 0.010908 \\
\hline S.E. of regression & 0.008696 & Akaike info criterion & & -6.382623 \\
\hline Sum squared resid & 0.000983 & Schwarz criterion & & -6.034117 \\
\hline Log likelihood & 70.82623 & Hannan-Quinn criter. & & -6.314591 \\
\hline F-statistic & 2.815645 & Durbin-Watson stat & & 1.962450 \\
\hline Prob(F-statistic) & 0.055564 & & & \\
\hline
\end{tabular}

Hasil Pengujian Secara Bersama-sama (Uji F)

Dalam jangka panjang dan pendek, hasil estimasi dapat diketahui bahwa nilai F-statistik sebesar 170.2578 dan 21.48285 dengan probabilitas statistik sebesar 0.000000 dan 0.000025 lebih kecil dari $\alpha=0.05$ menunjukkan 
bahwa secara bersama-sama (uji serempak) semua variabel indenpenden yaitu j_maskapai, j_pengangguran, j_penumpang, dan j_wisatawan serta Error Correction Term (ECT) memiliki pengaruh yang nyata terhadap produk domestik regional bruto di Sumatera Utara.

Hasil Pengujian Ketepatan Perkiraan (Uji R²)

Berdasarkan hasil estimasi, diperoleh nilai koefisien determinasi (R-square) dalam jangka panjang dan jangka pendek yaitu sebesar 0.907106 atau sebesar (90.71 persen), variasi perubahan variabel j_maskapai, j_pengangguran, j_penumpang, dan j_wisatawan. Sedangkan sisanya dalam jangka panjang dan jangka pendek sebesar 9.29 persen dijelaskan oleh variabel-variabel diluar model (yang tidak diteliti).

\section{SIMPULAN DAN SARAN}

Berdasarkan hasil estimasi terhadap model Error Correction Model mengenai pengaruh dari variabel-variabel independen seperti Ekspor, Impor, Inflasi, dan Suku Bunga terhadap variabel dependen Produk Domestik Regional Bruto di Sumatera Utara tahun 2000-2016, maka dapat disimpulkan, bahwa: Dari beberapa variabel bebas yang dicoba dan dimasukkan dalam persamaan produk domestik regiobal bruto di Sumatera Utara dengan menggunakan model Error Correction Model yaitu ekspor, impor, inflasi, dan suku bunga dalam jangka panjang hanya variabel jumlah penumpang yang tidak berpengaruh signifikan, sedangkan di jangka pendek semua variabel berpengaruh signifikan terhadap produk domestik regional bruto di Sumatera Utara. Berdasarkan kesimpulan yang dikemukakan sebelumnya, saran yang dapat dijadikan sebagai rekomendasi, adalah: pemerintahan Sumatera Utara perlu mengintegrasikan kebijakan dalam peningkatan pengembangan bandara silangit untuk memaksimalkan potensi objek wisata dalam mendorong peningkatan produk domestik regional bruto di Sumatera Utara.

\section{DAFTAR PUSTAKA}

Angkasa Pura II, 2017, Laporan Tahunan Annnual Report PT. Angkasa Pura II (Persero), Silangit.

Affandi, M.N. (2010). Pembangunan Infrastruktur Sebagai Pendukung. 
Bojanic, D.C \& Lo, M. (2016).A comparison of the moderating effect of tourism reliance on the economic development for islands and other countries. Tourism Management, Vol.53, Hal.207-214.

GÜL Hasan. 2013. Economic impacts of an increase in the Foreign tourism receipts: a sam - based income Multiplier analysis for Turkey. Advancein hospitality and tourism research (AHTR). 1(1): 17-36.

Gujarati, Damodar N. 2010. “Dasar-Dasar Ekonometrika”. Salemba Empat.

Jalil, A., Mahmood, T \& I,M. (2013). Tourism - growth nexus in Pakistan: Evidence from ARDL bounds tests. Economic Modelling, Vol.35, Hal.185-191.

Karel Fredrik Gaus Basar Lusnarnera, (2014), Strategic management plan formulation West southeast maluku airport Periode 2014-2018

Kurniawan, Wawan. 2015. Dampak Sosial Ekonomi Pembangunan Pariwisata Umbul Sidomukti Kecamatan Bandungan Kabupaten Semarang.Semarang: Skripsi Universitas Negeri Semarang

Leurent, L. (2011). kapasitas transportasi kendala pada sistem angkutan massal: analisis sistemik, Springer

Wardani, Mentari. 2016. Kontribusi Pengembangan pariwisata Danau Toba Melalui Skema Bop (Badan otorita Pariwisata) Bagi Masyarakat Di Sekitar danau Toba. Institut Pertanian Bogor: Bogor.

Nani Tambunan Dosen Universitas Mpu Tantular, Jakarta Majalah Ilmiah Panorama Nusantara, edisi VI, Januari - Juni 2009

Sukirno, Sadono. 2011. Ekonomi Pembangunan: Proses, Masalah dan Dasar Kebijakan. Jakarta: Kencana

Todaro, Michel P, \& Stephen C. Smith. 2011. Pembangunan Ekonomi. Edisi 1. Terjemahan Haris Munandar. Erlangga. Jakarta.

Widarjono, Agus, 2009. Ekonometrika Untuk Analisis Ekonomi dan Keuangan. Jakarta: UI 